\title{
Geophysical and geochemical analysis of shallow gas and an associated pockmark field in Bantry Bay, Co. Cork, Ireland
}

\author{
S.F. Jordan ${ }^{\mathrm{a}}$, S.S. O'Reilly ${ }^{\mathrm{b}}$, D. Praeg ${ }^{\mathrm{c}, \mathrm{d}}$, D. Dove ${ }^{\mathrm{e}}$, L. Facchin ${ }^{\mathrm{d}}$, R. Romeo ${ }^{\mathrm{d}}$, M. Szpak ${ }^{\mathrm{f}}$, X. Monteys ${ }^{\mathrm{f}}$, \\ B.T. Murphy ${ }^{\mathrm{a}}$, G. Scott ${ }^{\mathrm{g}}$, S.S. McCarron ${ }^{\mathrm{g}}$, B.P. Kelleher ${ }^{\mathrm{a}, *}$ \\ ${ }^{a}$ School of Chemical Sciences, Dublin City University, Dublin 9, Ireland \\ ${ }^{\mathrm{b}}$ Department of Earth, Atmospheric, and Planetary Sciences, Massachusetts Institute of Technology, Cambridge, MA, USA

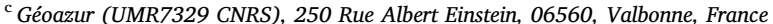 \\ ${ }^{\mathrm{d}}$ OGS (Istituto Nazionale di Oceanografia e di Geofisica Sperimentale), Borgo Grotta Gigante 42C, Trieste, 34010, Italy \\ ${ }^{\mathrm{e}}$ British Geological Survey, The Lyell Centre, Research Avenue South, Edinburgh, EH14 4AP, UK \\ ${ }^{\mathrm{f}}$ Geological Survey of Ireland, Beggars Bush, Haddington Road, Dublin, Ireland \\ ${ }^{\mathrm{g}}$ Maynooth University Department of Geography, Maynooth, Co. Kildare, Ireland
}

\section{A R T I C L E I N F O}

\section{Keywords:}

Seafloor

Pockmarks

Biogeochemical processes

Fluid migration

Anaerobic oxidation of methane (AOM)

Lipid biomarkers

Methane

Climate change

Geohazards

\begin{abstract}
A B S T R A C T
An integrated geophysical, geological, and geochemical investigation of seabed fluid venting was carried out in upper Bantry Bay, a large marine inlet on the southwest coast of Ireland. The results provide evidence of the seafloor venting of gas rich fluids, resulting in the formation of a pockmark field identified here for the first time. The pockmarks occur in an area where sub-bottom profiles provide evidence of chimney-like features interpreted to record upward gas migration through Quaternary sediments to the seafloor. Three vibrocores up to $6 \mathrm{~m}$ long were acquired in water depths of 24-34 m, two from the pockmark field and one from outside. Methane of predominantly biogenic origin was quantified in all three cores by headspace analysis of sediment sub-samples. Well-defined sulfate methane transition zones (SMTZs) were observed in two of the cores, the shallowest (1.25 m below sea floor (mbsf)) inside the pockmark field and the other ( $3.75 \mathrm{mbsf}$ ) outside. It is likely that an SMTZ occurs at the location of the third core, also within the pockmark field, although deeper than the samples obtained during this study. Gas migration towards the seafloor is suggested to involve both diffuse pore fluid migration across wide areas and focused flow through the pockmarks, together driven by methanogenesis of preglacial lacustrine sediments preserved in a bedrock basin, and possible gas release from the Owenberg River Fault. Analysis of phospholipid fatty acids (PLFAs) and archaeal isoprenoid hydrocarbons was used to investigate the microbial ecology of these sediments. Anaerobic oxidation of methane (AOM) may play a role in controlling release of $\mathrm{CH}_{4}$ to the water column and atmosphere in this shallow gas setting, potentially mediated by syntrophic sulfate reducing bacteria (SRB) and anaerobic methanotrophic archaea (ANME).
\end{abstract}

\section{Introduction}

Pockmarks are concave depressions within seabed sediments, circular to ellipsoidal in shape, ranging from $<1$ to $400 \mathrm{~m}$ in diameter and up to $20 \mathrm{~m}$ deep (Hovland and Judd, 1988; King and MacLean, 1970), although typically 30-40 m wide and 2-3 m deep (Acosta et al., 2001). Pockmarks can occur as singular features, in linear patterns known as pockmark trains, or in complex groups known as pockmark fields. The formation and dynamics of these features are still not fully understood, but they are generally considered to be the result of the expulsion of fluids typically including hydrocarbon gases, mainly methane $\left(\mathrm{CH}_{4}\right)$, from seafloor sediment (Hovland, 2013; Hovland and Judd, 1988). The emission of fluids containing gas from pockmarks makes them of interest in relation to issues of global carbon cycling and climate change, as well as for seafloor geohazards (Judd and Hovland, 2007).

Geologic Emissions of Methane (GEM), which include marine seeps such as pockmarks, have been recognized as a natural source of atmospheric methane second only to wetlands (Etiope et al., 2008). As a greenhouse gas, the warming potential of $\mathrm{CH}_{4}$ outweighs carbon dioxide $\left(\mathrm{CO}_{2}\right)$ by a factor of 25 times per ton, and since pre-industrial times is estimated to have been responsible for approximately $20 \%$ of the Earth's warming (Yvon-Durocher et al., 2014). Recent work indicates that contributions from marine sources have been greatly underestimated (Skarke et al., 2014) and there is a need for $\mathrm{CH}_{4}$ flux

\footnotetext{
* Corresponding author.

E-mail address: brian.kelleher@dcu.ie (B.P. Kelleher).
} 

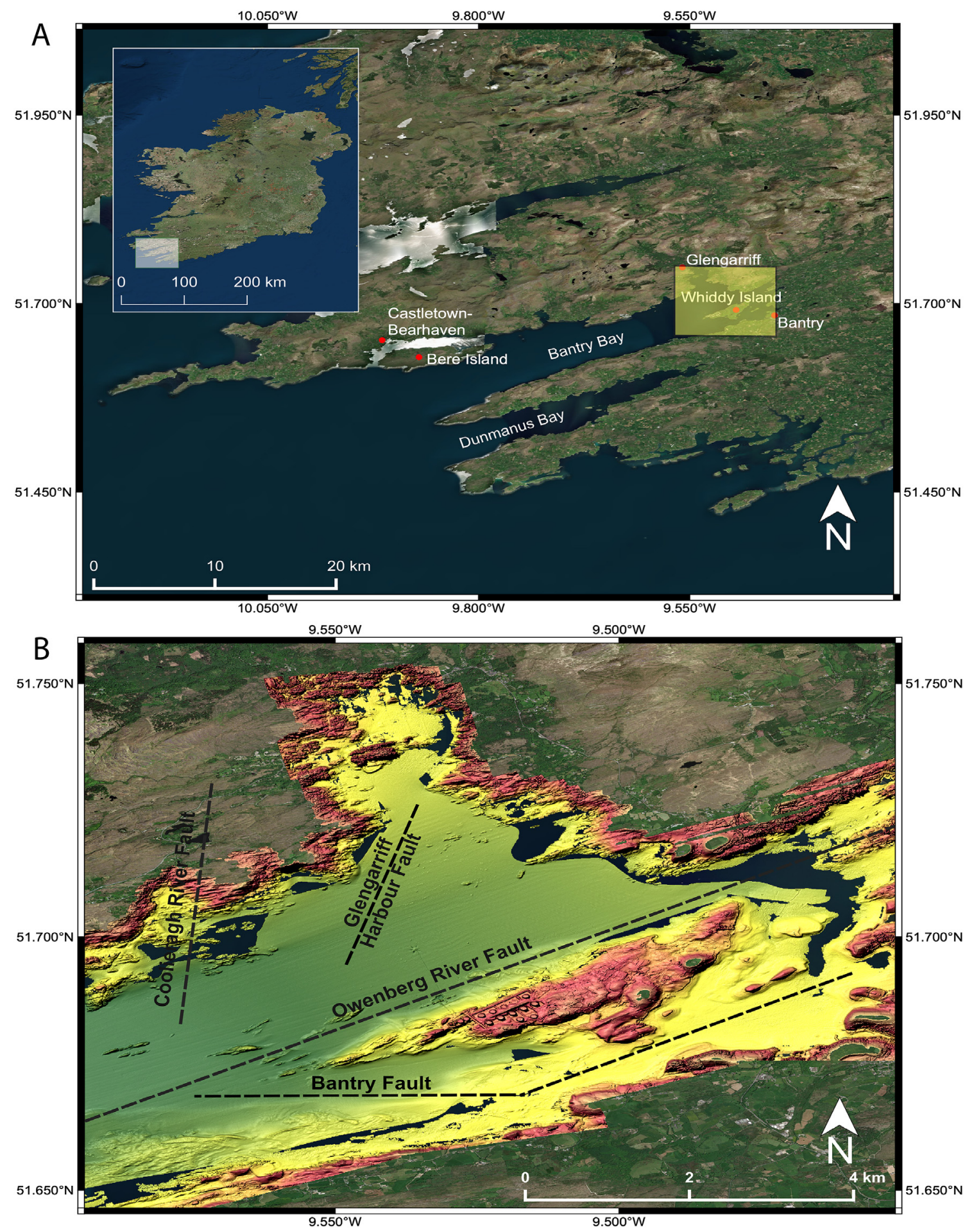

Fig. 1. (A) Map of Bantry Bay and surrounding area, location of Bantry Bay within Ireland (inset). (B) Bathymetric map of inner Bantry Bay showing locations of underlying faults.

revisions in terms of understanding the global carbon cycle (Judd and Hovland, 2007). Seepage sites are globally widespread in shallow water coastal regions and have been suggested to be an important source of $\mathrm{CH}_{4}$ (Borges et al., 2016; Janssen et al., 2005; Shakhova et al., 2010; Skarke et al., 2014). However, global estimates of the contribution to atmospheric $\mathrm{CH}_{4}$ concentrations from marine seepage sites are highly uncertain (Römer et al., 2014).

The presence of pockmarks may also be of significance in terms of marine geohazards (Hovland, 1989). Fluid migration through marine sediments, through its influence on pore pressures and sediment strength, is thought to play a key role in slope failure and seabed instability (e.g. Locat and Lee, 2002). Therefore in pockmarked areas the development of offshore infrastructures, such as pipelines, may need to avoid these features (Hovland et al., 2002). In addition, pockmarks have been suggested as possible indicators of seismic activity (Hovland et al., 2002), based on observations of gas venting from pockmarks before and during earthquakes at sites in California (Field and Jennings, 1987) and Greece (Hasiotis et al., 1996; Soter, 1999). Large-scale multinational monitoring of pockmarks has been advocated (Hovland et al., 2002). 
Anaerobic oxidation of methane (AOM) and the microbial consortia involved are important factors in the global methane cycle, and yet they are still poorly understood (Gauthier et al., 2015; Ruff et al., 2016). Although large amounts of $\mathrm{CH}_{4}$ are transported from deep reservoirs to shallow sediments, it is estimated that $<3 \%$ reaches the atmosphere due to the AOM performed by microbial communities (Niemann and Elvert, 2008). The predominant mechanism of AOM is thought to be a syntrophic process whereby anaerobic methanotrophic archaea (ANME) and sulfate reducing bacteria (SRB) oxidise $\mathrm{CH}_{4}$ to $\mathrm{CO}_{2}$ whilst reducing $\mathrm{SO}_{4}{ }^{2-}$ to $\mathrm{H}_{2} \mathrm{~S}$ providing energy for both microbial consortia (Boetius et al., 2000; Elvert et al., 2003; Reeburgh, 2007; Valentine and Reeburgh, 2000):

$\mathrm{SO}_{4}^{2-}+\mathrm{CH}_{4} \rightarrow \mathrm{HCO}_{3}{ }^{-}+\mathrm{H}_{2} \mathrm{~S}+\mathrm{H}_{2} \mathrm{O}$

These communities are predominantly found in sediments, however they have also been found in anoxic marine and saline lacustrine water bodies, and in terrestrial mud volcanoes (Alain et al., 2006; Joye et al., 1999; Wakeham et al., 2003). AOM primarily occurs at what is known as the sulfate methane transition zone (SMTZ), where $\mathrm{CH}_{4}$ diffusion from deeper sediments and $\mathrm{SO}_{4}{ }^{2-}$ penetration from seawater provide optimal conditions for AOM communities (Knittel and Boetius, 2009).

Lipid biomarkers can provide evidence for the role played by archaea and SRB in AOM (Caldwell et al., 2008). Phospholipid fatty acids (PLFAs) are fatty acids chemically cleaved from ester linkage to polar head groups and are a useful tool to provide quantitative measures of viable biomass and microbial community composition (Ringelberg et al., 1997; Zelles, 1997). Phospholipids are rapidly degraded after cell death making them excellent biomarkers for viable microbial cells (Navarrete et al., 2000; White et al., 1997). Certain PLFAs have been used as chemotaxonomic markers for $\mathrm{SRB}$, such as $\mathrm{C}_{16: 1 \omega 5 \mathrm{c}}$ and cyC $_{17: 0 \omega 5,6}$ as indicators of Desulfosarcina/Desulfococcus species (Elvert et al., 2003). Archaeal cell membranes are comprised of ether-linked isoprenoid lipids (Schouten et al., 2013). Analysis of these intact lipids or their hydrocarbon skeletons (e.g. phytane, acyclic and cyclic $\mathrm{C}_{40}$ isoprenoids) in environmental samples provides a broad measure of archaeal abundance and diversity (e.g. (King et al., 1998). $\delta^{13} \mathrm{C}$ values of AOM derived lipids are typically significantly depleted with values < -50\%o (Elvert et al., 2003; Niemann and Elvert, 2008; van Dongen et al., 2007). Isolation of these compounds combined with determination of their $\delta^{13} \mathrm{C}$ signatures can help provide an overview of the microbial consortia and their involvement in AOM within cold seep environments (Ge et al., 2015; Pancost et al., 2000).

Pockmark and seepage sites have been reported and investigated at several sites around the coast of Ireland and we are only beginning to understand the dynamics and ubiquity of coastal methane cycling (Croker et al., 2005; O'Reilly et al., 2014; Szpak et al., 2012, 2015). In this paper we present the first description of a pockmark field in the shallow waters $(<30 \mathrm{~m})$ of upper Bantry Bay, on the west coast of Ireland. The aim of the study is to characterise $\mathrm{CH}_{4}$ migration associated with the pockmarks, based on core data acquired during an Irishled campaign in 2014. The results provide information on the source of the $\mathrm{CH}_{4}$ and its relation to the microbial ecology of this area, as well as the possible causes of pockmark formation at this site. Our findings contribute to an improved understanding of gas venting features in Irish coastal waters, that may be relevant to environmental planning, economic developments, and global climate change.

\section{Regional setting}

Bantry Bay is the largest marine inlet in the southwest of Ireland, spanning an offshore area of $300 \mathrm{~km}^{2}$ (Fig. 1A). It is approximately $40 \mathrm{~km}$ long, narrowing in width from $10 \mathrm{~km}$ at its mouth, where water depths are up to $60 \mathrm{~m}$, to $5 \mathrm{~km}$ at its head. The bay contains two large islands; Bere Island in the outer bay and Whiddy Island in the inner bay. The Melagh, Owvane, Coomhola, Glengarriff, and Adrigole rivers all drain into Bantry Bay. Geologically, the bay lies within the South Munster Basin, comprising Devonian strata dominated by the Old Red Sandstone beneath uppermost Devonian and Carboniferous marine sandstones and mudstones (Plets et al., 2015; Vermeulen et al., 2000). Several fault lines are inferred to run through the bay offsetting the Old Red Sandstone (Fig. 1B): the Bantry Fault runs from the southeast of Whiddy Island, continuing along the centre of the bay; the Owenberg River Fault lies north east of Whiddy Island before meeting the Bantry Fault; while northeast of Whiddy Island are the Glengarriff Harbour and Coolieragh Faults (Szpak et al., 2015).

The sedimentary infill of the Bay was described by (Plets et al., 2015), based on sub-bottom profiles tied to shallow sediment cores, who recognized bedrock to be overlain by up to six units, interpreted to record deposition prior to and since the last glacial maximum (LGM). The oldest unit corresponds to stratified sediments infilling bedrock depressions, correlated to pre-LGM lacustrine sediments reported in the upper Bay by Stillman (1968). This is overlain by glacial sediments, truncated by tidal to estuarine units recording the inundation of the Bay and capped by a seafloor unit recording the establishment of fully marine conditions after $11 \mathrm{ka}$ BP. In the inner Bay, the upper stratified marine unit is underlain by a unit of strong discontinuous reflections described as 'turbid', that cores show to correspond to estuarine deposits, laminated sands and muds containing organic matter, suggested on the basis of its acoustic character to also contain pockets of gas (Plets et al., 2015). In addition, in the upper Bay above at least $65 \mathrm{~m}$ water depth, the sediment column is crossed by vertical, pillar-like acoustic turbidity zones (ATZs) that rise to within several metres of seafloor; although not interpreted by Plets et al. (2015), these appear typical of gas chimneys (Dondurur et al., 2011).

Seabed classification maps based on backscatter and particle size analysis (PSA) show that the sediment type is predominantly mud to fine sand with increasing medium to coarse sand towards the mouth of the bay. There are areas of medium to coarse sand, coarse sand to gravel, and rock throughout the bay primarily along the perimeter (INFOMAR, 2011).

\section{Materials and methods}

The data used in this study were acquired during campaigns undertaken as part of the INFOMAR (Integrated Mapping for the Sustainable Development of Ireland's Marine Resources) programme. Acoustic datasets including multibeam bathymetric and backscatter coverage of all of Bantry Bay were obtained during INFOMAR campaigns from 2004 to 2007 (see Plets et al., 2015), while the sediment cores and sub-bottom profiles used in this study were acquired as part of the GATEWAYS campaign of the Celtic Explorer in February 2014 (CE14003).

\subsection{Acoustic data}

Seafloor bathymetric and backscatter data were collected using two Kongsberg Simrad multibeam systems, an EM1002 (95 kHz) and an EM3002D (200 kHz). The multibeam data were processed using QTC Multiview software to generate bathymetric terrain models of $2 \times 2 \mathrm{~m}$ grid size. No multibeam water column data were available for this study.

Sub-bottom profiles were acquired in 2014 using a heave-corrected SES Probe 5000 pinger with a $4 \times 4$ transducer array (hull-mounted) and a CODA DA2000 acquisition system. Frequency content of $2.5 \mathrm{kHz}$ corresponds to decametric vertical resolution. Acquisition parameters, data logging, and interpretation were performed using the CODA Geokit suite.

\subsection{Sediment cores}

Three sediment cores were obtained in 2014 using a $6 \mathrm{~m}$ pneumatic 
vibrocorer, deployed in water depths of 24-34 m. Recorded positions are those of the ship, which may differ from the corer by up to $30 \mathrm{~m}$. Two cores were obtained from within the pockmark field and one core was taken from outside the field. Once on deck, cores were cut into $1 \mathrm{~m}$ sections and capped. Core sections were split and the archive halves were photographed and logged. Sediment porewaters were sampled downcore using Rhizons (Rhizosphere Research Products) for analysis of $\mathrm{SO}_{4}{ }^{2-}$ distribution. These were attached to $10 \mathrm{~mL}$ plastic syringes to create vacuum pressure. The sampled porewater was placed in a plastic vial and preserved with $10 \mu \mathrm{CHCl}_{3}$ for sulfate analysis. All porewater samples were refrigerated at $4{ }^{\circ} \mathrm{C}$ onboard for the duration of the cruise and back in the laboratory prior to analysis.

Gas samples were immediately taken from the vibrocore sections to determine gas composition and distribution. Two $10 \mathrm{~cm}^{3}$ sediment plugs were sampled using plastic syringes with tips removed and transferred to $50 \mathrm{~mL}$ glass headspace vials containing $20 \mathrm{~mL} 2 \mathrm{M}$ sodium hydroxide. Vials were sealed, homogenised, and stored upsidedown in the dark at $4{ }^{\circ} \mathrm{C}$ for the duration of the cruise.

Sediment sub-samples were taken immediately after porewater and gas sub-samples. Particle size analysis (PSA) samples were placed in ziplock bags and stored at room temperature. Samples for lipid biomarker analysis were wrapped in fired $\mathrm{Al}$ foil, placed in ziplock bags, and stored at $-20^{\circ} \mathrm{C}$.

\subsection{Porewater and gas analysis}

$\mathrm{SO}_{4}{ }^{2-}$ concentration in porewater was determined by the turbidimetric method. $10 \mathrm{~mL}$ of sample was stirred constantly and 2-3 drops of glycerol were added. Crushed $\mathrm{BaCl}_{2}$, approximately $50 \mathrm{mg}$, was added to the mixture and stirring was continued for $1 \mathrm{~min}$ after which an aliquot was taken and the absorbance measured at $420 \mathrm{~nm}$ on a Shimadzu UV Mini 1240. Further aliquots were taken after 2, 2.5, and $3 \mathrm{~min}$ and an average reading was calculated and used to determine concentration by extrapolation from a calibration curve. The calibration curve was prepared with $\mathrm{Na}_{2} \mathrm{SO}_{4}$ standards in a range of 10-100 ppm.

$\mathrm{CH}_{4}$ analysis was performed on an Agilent 7820A GC-FID with a $30 \mathrm{~m}$ HP-PLOTQ column (Agilent, Santa Clara, USA). Column conditions were isothermal $\left(50^{\circ} \mathrm{C}\right) . \mathrm{CH}_{4}$ was quantified using calibration standards prepared from a $99.995 \% \mathrm{CH}_{4}$ standard (Sigma Aldrich, Dorset, UK).

\subsection{Bulk physical and chemical analysis}

PSA and total organic carbon (TOC) data were obtained from subsamples taken surrounding the SMTZ locations which were determined by $\mathrm{CH}_{4}$ and $\mathrm{SO}_{4}{ }^{2-}$ analyses. PSA was determined by laser granulometry using a Mastersizer 2000 particle size analyser (Malvern, Worcestershire, UK). Organic carbon (OC) was removed using 30\% hydrogen peroxide $\left(\mathrm{H}_{2} \mathrm{O}_{2}\right)$ prior to analysis. Elemental analysis was performed in triplicate using a Fisons NCS 1500 NA elemental analyser. Samples were treated with $1 \mathrm{~N} \mathrm{HCl}$ in Ag capsules following the procedure of Verardo et al. (1990) to remove carbonate. After drying overnight, the capsules were wrapped in $\mathrm{Sn}$ boats and combusted in the presence of $\mathrm{O}_{2}$. The $\mathrm{CO}_{2}$ evolved was measured and the TOC content (\%) calculated by comparison with the certified reference standard acetanilide.

\subsection{Lipid biomarker analysis}

Sediment samples were selected from sub-samples associated with the SMTZs. These were freeze-dried and homogenized and lipid compounds were extracted from $30 \mathrm{~g}$ of powdered sediment using a modified Bligh-Dyer extraction (White et al., 1997). Total lipid extracts (TLEs) were concentrated and elemental $\mathrm{S}$ was removed by reaction with activated $\mathrm{Cu}$. TLEs were fractionated into neutral, glyco-, and polar lipids using Bond-Elut SPE columns packed with an aminopropylsilica solid phase $(5 \mathrm{~mm}$ diameter, PE, $500 \mathrm{mg}$ Ultra-Clean NH2, Agilent Technologies) as outlined by Pinkart et al. (1998). A portion of each polar lipid fraction was subjected to acid methanolysis $(0.5 \mathrm{M}$ sodium methoxide, $50{ }^{\circ} \mathrm{C}, 30 \mathrm{~min}$ ) to transmethylate ester-linked fatty acids. Double-bond positions of monounsaturated PLFAs were determined by the formation of dimethyl disulfide (DMDS) adducts as described by Nichols et al. (1986). Archaeal isoprenoid lipids were separated from polar head groups by cleavage of their ether linkages following the method of Trent et al. (2003). 100 ppm $5 \alpha$ cholestane was added to all derivatised fractions as an internal standard prior to analysis.

Aliquots $(1 \mu \mathrm{l})$ of samples were injected in triplicate onto an Agilent model $7890 \mathrm{~N}$ gas chromatograph coupled to an Agilent 5973N mass selective detector operating in electron impact mode at $70 \mathrm{eV}$. The column was a $30 \mathrm{~m}$ HP-5MS column $(0.25 \mathrm{~mm}$ i.d., $1 \mu \mathrm{m}$ film thickness). Each sample $(1 \mu \mathrm{l})$ was injected with a $2: 1$ split ratio. The GC inlet temperature was $280^{\circ} \mathrm{C}$ and the oven programme was $65^{\circ} \mathrm{C}$ (held $2 \mathrm{~min}$ ) to $300^{\circ} \mathrm{C}$ (held $20 \mathrm{~min}$ ) at $6^{\circ} \mathrm{C} / \mathrm{min}$. Individual compounds were assigned from comparison with mass spectral library databases (NIST and Wiley) and comparison of MS patterns with published spectra and authentic standards. Analytes were quantified from total ion peak area using multiple-point calibration curves of representative standards (methyl tetradecanoate and squalane). Percentage recovery was measured using an internal standard added prior to extraction and was found to be $>95 \%$. Procedural blanks were run to monitor background interferences.

$1 \mu \mathrm{l}$ aliquots of samples were injected in triplicate onto an Agilent model $7890 \mathrm{~N}$ gas chromatograph coupled to an IsoPrime 100 isotope ratio mass spectrometer. The $\delta^{13} \mathrm{C}$ values were measured against a $\mathrm{CO}_{2}$ reference gas of known $\delta^{13} \mathrm{C}$ value and are reported vs. a stable isotope reference standard ( $n$-alkanes mixture B2, Indiana University, USA). Reproducibility was better than $\pm 0.5 \%$ and only well resolved major analytes are reported here.

Lipid nomenclature is according to $\mathrm{xCy} \omega \mathrm{z}$, where $\mathrm{x}$ refers to the number of carbon atoms present, $y$ refers to the number of double bonds on the carbon chain and $\mathrm{z}$ refers to the position of the first double bond from the methyl end. Iso and anteiso branching is denoted by ' $i$ ' and ' $a i$ ' respectively whilst the presence of the cyclopropane ring in a compound is denoted by 'cy'.

\section{Results}

\subsection{Geophysical analyses}

Multibeam morpho-bathymetric data provide evidence of an elongate pockmark field north of Whiddy Island (Fig. 2). This is a narrow (max width ca. $275 \mathrm{~m}$ ) pockmark field of approximately $2.4 \mathrm{~km}$ in length, covering an area of ca. $0.5 \mathrm{~km}^{2}$. Interestingly, this field coincides with part of the Owenberg River Fault (Fig. 1B). The data show that the pockmarks average ca. $10 \mathrm{~m}$ in diameter and are of low relief, with some features near the core locations as shallow as ca. $0.3 \mathrm{~m}$ in depth (Fig. 2B). Recorded GPS position onboard the vessel may differ from the actual sample location by up to $20-30 \mathrm{~m}$. Therefore, although both VC24 and VC25 were taken within the pockmark field, it is not possible to be sure whether either core penetrated directly into a single pockmark feature.

A sub-bottom profile for VC27 was not prepared as the data was obstructed by sideswipe from a rocky outcrop. Sub-bottom profiles across the sites of VC24 and VC25 provide acoustic evidence of gas migration through the sediment column (Fig. 3). The sedimentary succession is crossed by columnar or conical zones of blanking ( $\mathrm{AB}$ on Fig. 3), most of which underlie strong reflector segments that lie at varying depths of ca. 4-10 m below sea floor (mbsf) (Fig. 3). Similar 'pillar-like' acoustic zones were previously described on sub-bottom profiles across upper Bantry Bay by Plets et al. (2015). On high 


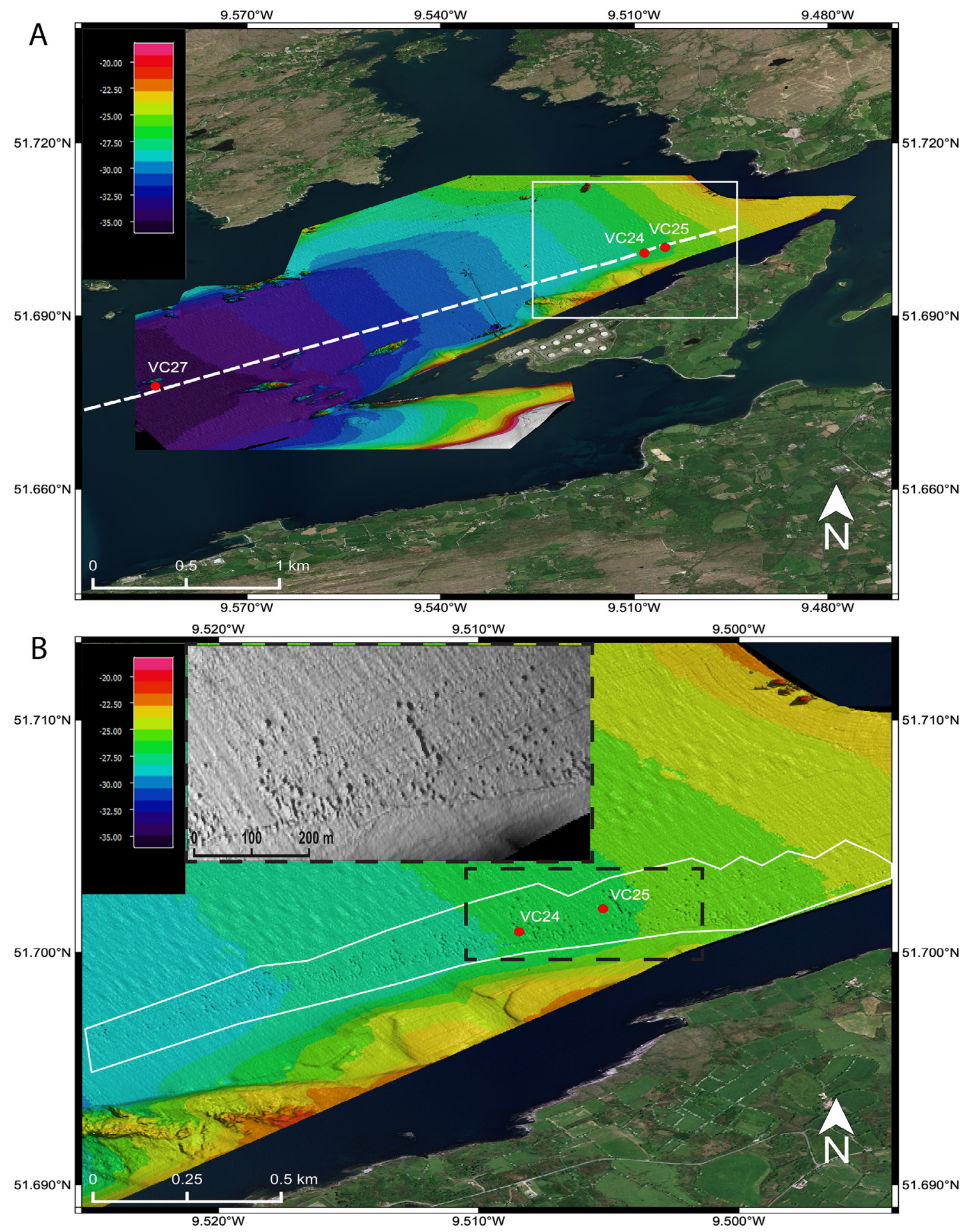

Figure 2. (A) Bathymetric map of inner Bantry Bay, vibrocore locations marked with red dots. The pockmark field north of Whiddy Island is located within the white box. (B) Close up of pockmark field from (A) with the entire field highlighted by a white outline and vibrocore locations marked with red dots. A close up of the section of the pockmark field within the black dashed rectangle is also depicted (inset).

frequency seismic data, such effects may arise due to overlap with the resonance frequencies of gas bubble populations, resulting in energy loss by attenuation (reverberation and scattering) as well as changes in P-wave velocity (Mathys et al., 2005). Gas concentrations as low as $0.5 \%$ may result in a range of possible amplitude and coherence effects described as acoustic turbidity (Abegg and Anderson, 1997; Fleischer et al., 2001; Judd and Hovland, 2007). We interpret the vertical acoustic zones observed in Bantry Bay to be typical chimney structures, recording the upward migration of gas-rich fluids through the sediment column (e.g. Dondurur et al., 2011).

On Fig. 3, the tops of the chimneys are seen to lie at varying stratigraphic levels, the shallowest within an interval of strong discontinuous reflections of varying thickness. This interval corresponds to unit III of Plets et al. (2015), which their cores showed to comprise organic-rich laminated sands/muds of estuarine origin, hypothesised to contain gas pockets due to their acoustically 'turbid' character. This unit was also penetrated by our cores, which provide no evidence that its acoustic character can be correlated to higher gas content. We 


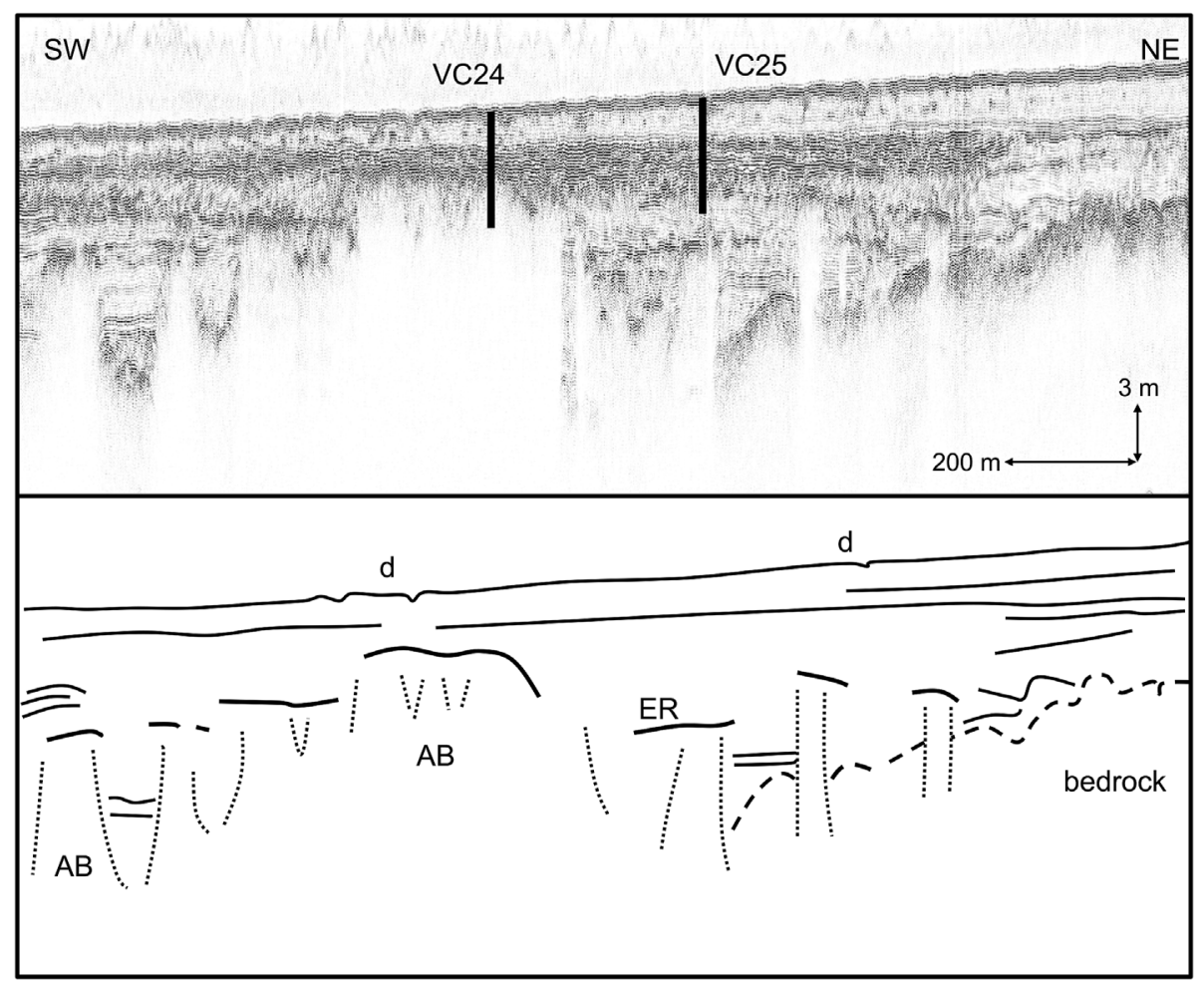

Fig. 3. Sub-bottom profiles taken at the site of VC24 and VC25 vibrocores showing sampling locations (black line), enhanced reflectors (ER), and acoustic blanking (AB).

suggest instead that the reflective character is likely to reflect the unit's distinctive lithology, comprising sand and mud laminae capable of generating strong impedance contrasts (SI Fig. S1).

\subsection{Gas and porewater geochemistry}

All measured $\mathrm{CH}_{4}$ values are provided in the supporting information (SI Table S1). The highest concentrations of $\mathrm{CH}_{4}$ were observed in VC24, taken from the pockmark field (Fig. 4). Values fluctuated between 2.62 and $3.57 \mathrm{mM}$ rising through the core before steadily decreasing from $3.28 \mathrm{mbsf}(3.68 \mathrm{mM})$ to the surface sample at $0.01 \mathrm{mbsf}$ $(0.002 \mathrm{mM})$, the minimum overall value for $\mathrm{VC} 24 . \mathrm{SO}_{4}{ }^{2-}$ concentrations for VC24 ranged from 7.0 to $26.8 \mathrm{mM}$ displaying an overall decreasing trend from the surface, opposite to that of $\mathrm{CH}_{4}$ (Fig. 4). A minimum value was observed at $2.12 \mathrm{mbsf}$ from which concentrations remain relatively constant through to the bottom of the core.

Overall $\mathrm{CH}_{4}$ concentrations detected within VC25 were the lowest of the three vibrocores analysed with a maximum observed at $5.23 \mathrm{mbsf}$ $(0.018 \mathrm{mM})$ and a minimum observed at $1 \mathrm{mbsf}$ (Fig. 4). Concentrations decrease gradually from the base of the core to the sediment surface from $0.016 \mathrm{mM}$ to $0.003 \mathrm{mM}$. Concentrations of porewater $\mathrm{SO}_{4}{ }^{2-}$ were relatively high throughout VC25 compared to VC24 and VC27 (Fig. 4). Values were gradually depleted from the seafloor $(0.17 \mathrm{mbsf})$ with a concentration of $22.1 \mathrm{mM}$ to the deepest sample from the core (5.66 mbsf) with a concentration of $12.0 \mathrm{mM}$.

In VC27, outside the pockmark field, $\mathrm{CH}_{4}$ concentrations decreased from $3.66 \mathrm{mM}$ at the base of the core $(4.96 \mathrm{mbsf})$ to $0.97 \mathrm{mM}$ at 4.08 mbsf before falling sharply to $0.07 \mathrm{mM}$ at $3.6 \mathrm{mbsf}$ (Fig. 4). Depletion gradually continued from this depth to $0.001 \mathrm{mM}$ at the surface of the core $(0.02 \mathrm{mbsf}) . \mathrm{SO}_{4}{ }^{2-}$ concentrations followed an opposing trend with a maximum of $23.9 \mathrm{mM}$ at $0.02 \mathrm{mbsf}$ decreasing to a minimum of $7.1 \mathrm{mM}$ at $4.08 \mathrm{mbsf}$ and remained at similar concentration to the base (4.96 mbsf) (Fig. 4).

\subsection{PSA and elemental analysis}

The overall sediment type for the three cores taken from Bantry Bay was poorly to very poorly sorted sandy mud. All values for mean particle size, percentage clay, silt, sand, and gravel are provided in Table 1. Mud percentages (clay and silt) ranged from 69.4 to $92.3 \%$ in VC24, from 42.2 to $81.2 \%$ in VC25, and from 29.3 to $84.0 \%$ in VC27. The $42.2 \%$ value from VC25 was obtained at $4.99 \mathrm{mbsf}$, a sample comprised of poorly sorted muddy sand due to its high sand content (57.8\%). The $29.3 \%$ value in VC27 was obtained at 1.93 mbsf where sediment type can be described as very poorly sorted, slightly gravelly, muddy sand due to its gravel $(4.9 \%)$ and sand $(65.8 \%)$ content. This gravel-containing layer had the largest mean particle size of 0.8 phi whereas the lowest value of 5.3 phi was observed in VC24 at 0.77 mbsf, the layer with the highest overall mud content (92.3\%). The mean particle size for the remaining samples ranged between 4.5 and 3.3 phi.

Total organic carbon (TOC) content was low throughout all cores with an average overall value of $0.6 \%$ (Table 2). The highest observed values were 2 and $1.2 \%$ for VC24 0.025 and 0.27 mbsf respectively. No other sample had a value greater than $0.7 \%$. In VC24, TOC decreased from 0.025 to $1.93 \mathrm{mbsf}(2-0.3 \%)$ before increasing slightly to $0.5 \%$ at $2.92 \mathrm{mbsf}$ and decreasing again to $0.3 \%$ at $3.9 \mathrm{mbsf}$. VC25 values were relatively constant. The TOC content of VC27 at 1.93 and 2.96 mbsf was $0.5 \%$. This decreased to $0.4 \%$ at $3.98 \mathrm{mbsf}$ and $0.3 \%$ at $4.97 \mathrm{mbsf}$.

\subsubsection{Lipid biomarkers}

A summary of key lipid biomarker concentrations is provided in Table 2. The highest overall concentrations of PLFAs in all three vibrocores were observed in VC24.310.1 and $235.2 \mu \mathrm{gOC}^{-1}$ were detected at 0.03 and 0.27 mbsf respectively, the largest quantities of PLFAs in all analysed samples. The remaining depths of VC24 contained between 31.1 ( $0.77 \mathrm{mbsf}$ ) and $90.1 \mu \mathrm{gOC}^{-1}$ (1.93 mbsf). Saturated fatty acids (SATFAs) and monounsaturated fatty acids (MUFAs) were the dominant PLFAs at 0.03 and 0.27 mbsf whilst SATFAs and branched fatty acids (brFAs) were dominant from 0.77 to $3.9 \mathrm{mbsf}$. 


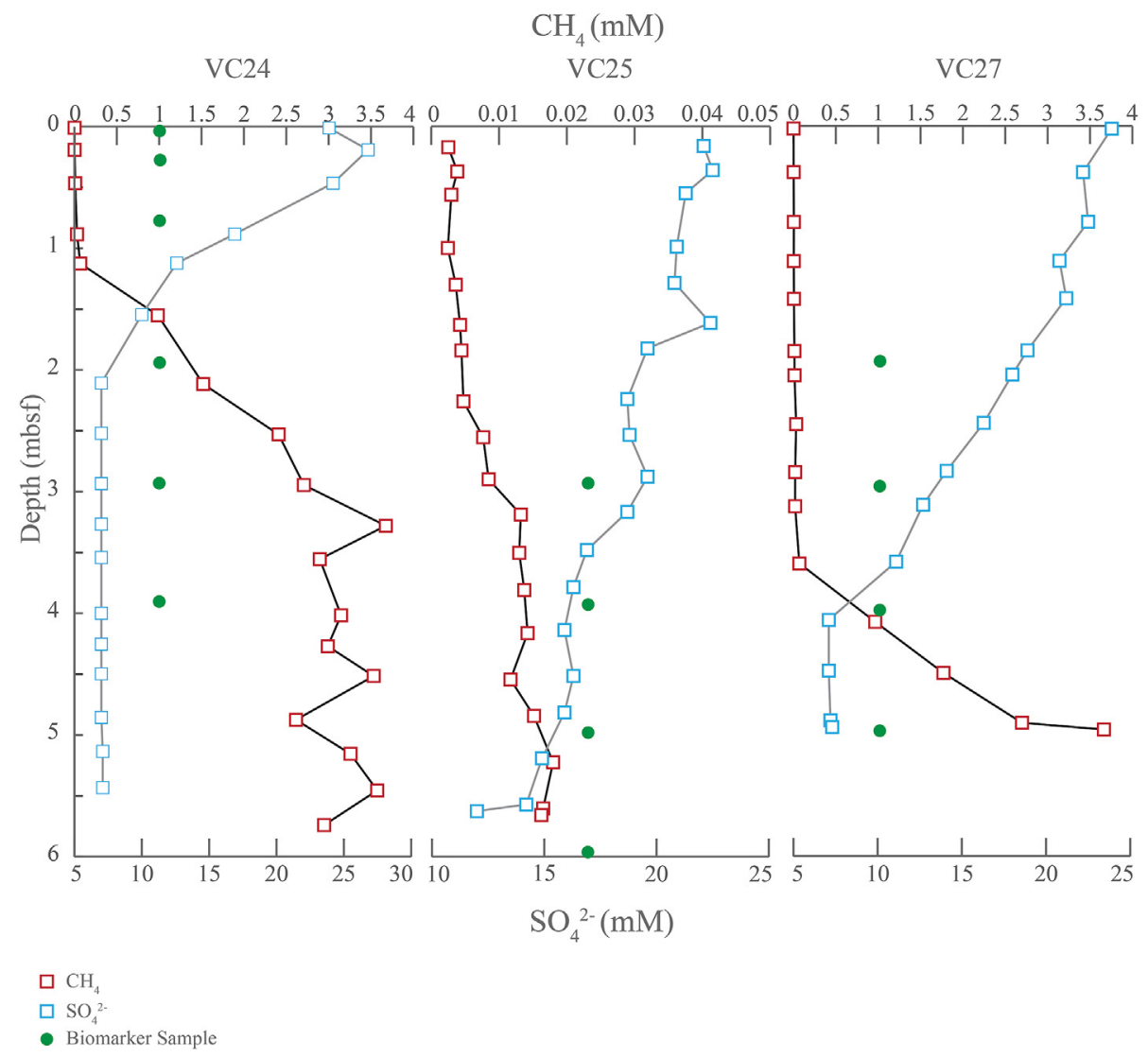

Fig. 4. $\mathrm{CH}_{4}(\mathrm{mM})$ and $\mathrm{SO}_{4}{ }^{2-}(\mathrm{mM})$ profiles for each core. Green dots represent sub-sampling locations for lipid biomarker analysis.

Table 1

PSA results for all vibrocores.

\begin{tabular}{lllllll}
\hline Core & Depth (mbsf) & Mean (phi) & Clay (\%) & Silt (\%) & Sand (\%) & Gravel (\%) \\
\hline \multirow{2}{*}{ VC24 } & 0.08 & 4.5 & 10.6 & 69.4 & 20 & 0 \\
& 0.33 & 3.3 & 10.1 & 62.8 & 27.1 & 0 \\
& 0.72 & 5.3 & 15.3 & 77 & 7.7 & 0 \\
& 1.88 & 4.0 & 9.7 & 68.9 & 21.4 & 0 \\
& 2.97 & 3.7 & 6.2 & 77.2 & 16.6 & 0 \\
& 3.96 & 3.8 & 5.5 & 63.9 & 30.6 & 0 \\
VC25 & 0.81 & 3.7 & 2.3 & 63.5 & 34.2 & 0 \\
& 2.93 & 3.4 & 6.1 & 62.8 & 31.1 & 0 \\
& 3.93 & 4.3 & 8.4 & 72.7 & 18.8 & 0 \\
VC27 & 4.99 & 3.6 & 1.8 & 40.4 & 57.8 & 0 \\
& 0.93 & 0.8 & 2.7 & 26.6 & 65.8 & 4.9 \\
& 1.96 & 4.1 & 11.9 & 72.1 & 16 & 0 \\
& 2.98 & 4.1 & 10.9 & 69.1 & 20 & 0 \\
& 3.97 & 3.4 & 11.7 & 41 & 47.3 & 0 \\
\hline
\end{tabular}

Polyunsaturated fatty acids (PUFAs) were not found at 1.93 or 2.92 mbsf and were the smallest class of PLFAs at all other depths. Total PLFA concentrations ranged from 49.7 to $73.9 \mu \mathrm{g} \mathrm{gOC}^{-1}$ (5.96 and 2.93 mbsf respectively) in VC25. SATFAs were the dominant compounds throughout the core with concentrations approximately 10 times greater than MUFAs and brFAs. There were no PUFAs observed in any VC25 samples. The highest concentration of PLFAs in VC27 was $77.4 \mu \mathrm{g}$ $\mathrm{gOC}^{-1}$ observed at $3.98 \mathrm{mbsf}$. The lowest concentration was $51.2 \mu \mathrm{g}$ $\mathrm{gOC}^{-1}$ which was observed at $1.93 \mathrm{mbsf}$. Similar to VC25, total SATFA concentrations were significantly greater than other PLFA classes. There was little variation in total concentrations of other PLFA classes throughout the core.

Five archaeal ether (AE) lipids were isolated from each sample taken from VC24, VC25, and VC27. These were; phytane, acyclic biphytane $\left(c y \mathrm{C}_{40: 0}\right)$, and three cyclic biphytanes $\left(c y \mathrm{C}_{40: 1}, c y \mathrm{C}_{40: 2}\right.$, and
${ } \mathrm{C}_{40: 3}$ ). The $c y \mathrm{C}_{40: 0}$ was the major isoprenoid in all samples whilst the cy40:1 was the minor isoprenoid.

\subsection{Carbon isotope values of individual PLFAs}

$\delta^{13} \mathrm{C}$ values could not be obtained for most lipid compounds identified in the three Bantry Bay vibrocores. This was due to a combination of low abundance in polar lipid extracts and low sensitivity of the GCIRMS instrument. $\delta^{13} \mathrm{C}$ values for three PLFAs were measured in the VC24 0.27 sample which contribute to the study of these sediments. The MUFAs $\mathrm{C}_{16: 1 \omega 7}$ and $\mathrm{C}_{16: 1 \omega 5}$ provided $\delta^{13} \mathrm{C}$ values of $-31.0 \%$ and $-46.1 \%$ respectively, and the SATFA $C_{16: 0} \delta^{13} \mathrm{C}$ value was $-27.7 \%$.

\section{Discussion}

Methane is widespread within upper Bantry Bay, as shown here through both acoustic evidence and millimolar concentrations of $\mathrm{CH}_{4}$ in core samples. Migration of gas-rich fluids towards the seafloor is interpreted to have led to the formation of pockmarks, which we describe here for the first time. Detailed geochemical analysis of porewater samples coupled to results from the gas analysis of sediment plugs, depict strong SMTZs occurring in two of three sediment core locations. Results from the third core, VC25, suggest that a similar SMTZ likely occurs below the maximum penetration depth of the vibrocorer. Lipid biomarker analysis provides evidence of the presence of active communities of both SRB and archaea within these sediment cores. These archaea are potentially anaerobic methanothrophs (ANME) which are likely involved in AOM, contributing to the prevention of regular methane seepage above the seafloor as evidenced by the distinct SMTZs.

Sub-bottom profiles provide evidence of vertical gas migration through the sediments of upper Bantry Bay, although no gas signals were observed within the water column, geochemical data provide 
Table 2

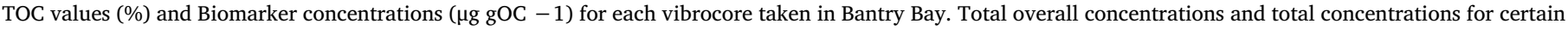

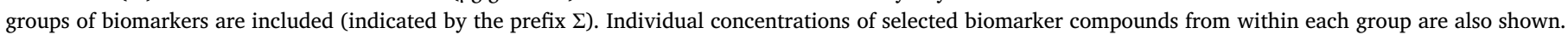
Depth in mbsf.

\begin{tabular}{|c|c|c|c|c|c|c|c|c|c|c|c|c|c|c|}
\hline & VC24 & & & & & & VC25 & & & & VC27 & & & \\
\hline Depth & 0.025 & 0.270 & 0.768 & 1.933 & 2.920 & 3.895 & 2.930 & 3.925 & 4.980 & 5.960 & 1.930 & 2.960 & 3.980 & 4.970 \\
\hline TOC & 2.0 & 1.2 & 0.6 & 0.3 & 0.5 & 0.3 & 0.3 & 0.3 & 0.3 & 0.3 & 0.5 & 0.5 & 0.4 & 0.3 \\
\hline$\Sigma$ PLFA & 310.14 & 235.24 & 31.07 & 90.12 & 51.21 & 44.02 & 73.90 & 57.15 & 56.90 & 49.68 & 51.24 & 68.89 & 77.36 & 63.01 \\
\hline$\Sigma$ SATFA & 133.28 & 118.72 & 20.43 & 64.94 & 33.06 & 30.99 & 52.11 & 41.72 & 42.73 & 43.24 & 36.15 & 42.50 & 50.35 & 46.84 \\
\hline$\Sigma$ MUFA & 91.12 & 51.97 & 2.61 & 2.25 & 3.40 & 1.94 & 5.18 & 3.86 & 1.35 & 8.54 & 4.22 & 5.89 & 5.99 & 5.78 \\
\hline ¿PUFA & 12.92 & 17.73 & 0.00 & 0.00 & 0.00 & 1.16 & 0.00 & 0.00 & 0.00 & 0.00 & 1.15 & 1.66 & 1.73 & 0.00 \\
\hline$\Sigma$ brFA & 64.58 & 32.62 & 4.31 & 4.44 & 12.15 & 7.62 & 7.19 & 5.09 & 5.17 & 4.38 & 4.91 & 4.90 & 4.50 & 5.25 \\
\hline$\Sigma \mathrm{AE}$ & 4.67 & 5.40 & 7.39 & 13.37 & 19.30 & 11.75 & 11.35 & 4.25 & 9.18 & 6.93 & 11.20 & 10.28 & 9.37 & 5.98 \\
\hline \multicolumn{15}{|l|}{ SATFA } \\
\hline $12: 0$ & 0.78 & 0.65 & 0.10 & - & - & - & 0.25 & - & 0.19 & - & 0.16 & 0.14 & 0.18 & - \\
\hline 13:0 & 0.35 & 0.27 & 0.05 & - & - & - & 0.07 & - & 0.08 & - & 0.11 & 0.13 & 0.12 & 0.11 \\
\hline $14: 0$ & 7.34 & 6.85 & 1.36 & 0.98 & 1.43 & 0.94 & 2.00 & 1.06 & 1.60 & 1.12 & 1.81 & 1.82 & 1.58 & 1.78 \\
\hline $15: 0$ & 2.69 & 2.27 & 0.63 & 0.54 & 0.77 & 0.54 & 0.82 & 0.60 & 0.73 & 0.61 & 0.91 & 0.83 & 0.63 & 0.71 \\
\hline $16: 0$ & 28.08 & 20.90 & 6.38 & 5.77 & 8.21 & 5.73 & 8.65 & 7.04 & 6.14 & 7.29 & 8.32 & 6.46 & 8.03 & 8.82 \\
\hline $17: 0$ & 2.52 & 1.16 & 0.33 & 0.47 & 1.58 & 0.40 & 0.53 & 0.52 & 0.46 & 0.53 & 0.52 & 0.62 & 0.57 & 0.65 \\
\hline 18:0 & 10.40 & 2.49 & 1.75 & 2.55 & 3.68 & 2.30 & 3.32 & 2.89 & 3.53 & 3.09 & 2.69 & 3.48 & 3.97 & 4.33 \\
\hline 19:0 & 2.70 & 5.54 & 0.28 & 0.50 & 0.56 & 0.93 & 0.71 & 0.90 & 0.51 & & 0.60 & 0.62 & 0.73 & 0.76 \\
\hline \multicolumn{15}{|l|}{ MUFA } \\
\hline $16: 1 \omega ?$ & 16.26 & 4.27 & 0.32 & 0.39 & 0.48 & 0.41 & 0.35 & 0.37 & 0.40 & 0.31 & 0.36 & 0.44 & 0.47 & 0.54 \\
\hline $16: 1 \omega 7$ & 2.67 & 0.88 & - & - & - & - & - & - & - & - & - & - & - & - \\
\hline $16: 1 \omega 5$ & 5.72 & 2.40 & 0.19 & - & - & - & - & - & - & - & 0.21 & 0.20 & & \\
\hline $18: 1 \omega 9$ & 12.09 & 0.83 & 0.48 & 1.28 & 0.73 & 1.00 & 0.92 & 0.99 & 0.95 & 1.25 & 0.91 & 0.98 & 0.67 & 0.78 \\
\hline $18: 1 \omega 7$ & 24.80 & 9.96 & 0.40 & 0.59 & 0.41 & - & - & - & - & - & 0.45 & & 0.84 & 0.86 \\
\hline 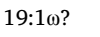 & 10.61 & 3.05 & 1.22 & 4.46 & 1.78 & 1.09 & 3.91 & 2.50 & 2.90 & - & 2.29 & 4.27 & 4.01 & 3.60 \\
\hline \multicolumn{15}{|l|}{ PUFA } \\
\hline $18: 2 \omega ?$ & - & - & - & - & - & - & - & - & - & - & 0.44 & 0.56 & 0.67 & - \\
\hline $20: 4 \omega 6$ & 3.77 & 3.05 & - & - & - & - & - & - & - & - & - & - & - & - \\
\hline $20: 5 \omega 3$ & 3.71 & 5.54 & - & - & - & - & - & - & - & - & - & - & - & - \\
\hline \multicolumn{15}{|l|}{ brFA } \\
\hline i13:0 & 0.43 & 0.24 & 0.06 & - & - & - & 0.09 & - & 0.06 & - & 0.10 & 0.10 & 0.07 & - \\
\hline ai13:0 & 0.58 & 0.40 & 0.05 & - & - & - & 0.13 & - & 0.08 & - & 0.16 & 0.15 & 0.10 & - \\
\hline i15:0 & 7.68 & 3.37 & 0.47 & 0.61 & 0.77 & 0.75 & 0.79 & 0.55 & 0.53 & 0.45 & 0.63 & 0.66 & 0.55 & 0.60 \\
\hline ai15:0 & 14.39 & 7.55 & 0.90 & 1.17 & 0.54 & 0.54 & 1.69 & 1.12 & 1.24 & 1.17 & 1.56 & 1.41 & 1.14 & 1.21 \\
\hline 3Me15:0 & - & - & - & - & - & - & 0.25 & - & - & - & 0.29 & 0.52 & 0.35 & 0.36 \\
\hline i16:0 & 3.18 & 2.40 & - & - & - & 0.53 & 0.70 & 0.78 & - & - & 0.56 & 0.67 & 0.51 & 0.47 \\
\hline$i 17: 0$ & 2.13 & 1.36 & 0.18 & 0.43 & 0.27 & 0.38 & 0.29 & 0.32 & 0.39 & 0.85 & 0.30 & 0.29 & 0.27 & 0.26 \\
\hline ai17:0 & 1.72 & 2.46 & 0.28 & 0.56 & 0.34 & 0.40 & 0.50 & 0.39 & 0.47 & 0.53 & 0.47 & 0.50 & 0.41 & 0.40 \\
\hline \multicolumn{15}{|l|}{ cyFA } \\
\hline cy $17: 0$ & - & 4.36 & - & - & - & - & - & - & - & - & - & - & - & - \\
\hline \multicolumn{15}{|l|}{$\mathrm{AE}$} \\
\hline Phytane & 0.76 & 0.64 & 0.72 & 1.43 & 1.63 & 0.86 & 1.24 & 0.47 & 0.85 & 0.81 & 0.94 & 1.51 & 1.30 & 0.98 \\
\hline C40:0 & 2.28 & 2.72 & 3.47 & 5.80 & 8.25 & 4.75 & 5.04 & 1.79 & 4.24 & 3.19 & 5.62 & 4.40 & 4.26 & 2.95 \\
\hline C40:1 & 0.36 & 0.51 & 0.44 & 1.67 & 1.74 & 1.44 & 0.92 & 0.45 & 0.71 & 0.51 & 0.81 & 0.76 & 0.75 & 0.31 \\
\hline C40:2 & 0.70 & 0.81 & 1.45 & 2.31 & 3.69 & 2.50 & 2.20 & 0.88 & 1.74 & 1.23 & 2.03 & 1.86 & 1.41 & 0.88 \\
\hline C40:3 & 0.57 & 0.72 & 1.31 & 2.16 & 3.99 & 2.21 & 1.94 & 0.67 & 1.64 & 1.19 & 1.79 & 1.75 & 1.65 & 0.87 \\
\hline
\end{tabular}

evidence of low concentrations of gas just beneath the seafloor. In the area of the pockmark field where our sediment cores were obtained, we observed vertical zones of acoustic blanking $(\mathrm{AB})$ beneath strong reflectors at varying depths below the seafloor, which we interpret as typical gas chimneys (Fig. 3). The observation of chimney-like features as well as of blanking below enhanced reflectors suggest upward fluid migration is predominant at this location (Szpak et al., 2012). Similar acoustic chimneys were observed to rise to within a few metres of the seafloor across upper Bantry Bay above water depths of at least $65 \mathrm{~m}$ by Plets et al. (2015, their Fig. 10a), which we interpret to indicate the upward migration of gas from depth over wide areas beneath the pockmark field. However, our results do not support the suggestion of Plets et al. (2015) that the presence of gas may account for the reflective character of their unit III, penetrated by our cores at ca. 2-6 mbsf (Fig. 3), which we instead suggest is due to its laminated lithological character (SI Fig. S1).
All gas headspace samples yielded undetectable amounts of $\mathrm{C}_{2}-\mathrm{C}_{4}$ hydrocarbons, indicating a biogenic source, rather than thermogenic source for gas in Bantry Bay (Faber and Stahl, 1984; Floodgate and Judd, 1992). The likely origins of this biogenic gas are microbial decomposition of buried organic matter and methanogenesis (Antler et al., 2014; Froelich et al., 1979). River run-off likely delivers a significant amount of OM to the bay. However, the majority of this terrestrially derived $\mathrm{OM}$ is likely consumed in the surface sediments as seen from the TOC results obtained from VC24. As such, this OM is probably not a large contributor to $\mathrm{CH}_{4}$ generation within Bantry Bay. Previous work in Bantry Bay encountered black lacustrine sediments at ca. $57 \mathrm{~m}$ water depth (ca. $25 \mathrm{mbsf}$ ) which were dated to 13-14 ka cal. BP within a borehole off Whiddy Island (Stillman, 1968). Plets et al. (2015) found that these deposits occurred within Unit 2 of their assigned seismo-stratigraphy profile. They suggested that the material was likely older than the value provided by Stillman (1968) as they 
were situated below acoustic Unit 4 which was described as a possible glacial till, thereby placing Unit 2 in the position of a pre-Last Glacial Maximum (LGM) deposit. The LGM is defined as 26.5-19 ka BP (Clark et al., 2009). These sediments likely undergo enhanced anaerobic decomposition and methanogenic activity due to their high organic content which makes them favourable candidates for the source of the gas observed in this area, however this awaits further investigation.

The pockmark field north of Whiddy Island is comprised of very shallow depressions of ca. $0.3 \mathrm{~m}$ depth. Due to the substantial gas activity observed in these sediments it is likely that biogenic $\mathrm{CH}_{4}$ resulting from the decomposition of organic material, possibly from ancient lacustrine deposits buried deep beneath the seafloor, was the primary cause of pockmark formation. Although no active seepage from pockmarks to the water column was observed in this study it is still possible that some of them are actively venting. Wheeler (2002) determined that significant currents regularly resuspend the seabed near Whiddy island. If the pockmarks were inactive, this could suggest that they have been filled in by fresh sediment. However, recent work suggests that inactive pockmarks can in fact be kept open by ocean currents (Hammer et al., 2009; Pau et al., 2014). Many studies have proposed that accumulation of large volumes of gas below the seafloor followed by periodic large expulsions is the predominant cause of pockmark formations (Cole et al., 2000; Dondurur et al., 2011; Gay et al., 2007; Hovland et al., 2002; Hovland and Judd, 1988). As such, these events likely reform the present features in Bantry Bay and potentially form new features as well. Further bathymetric analysis of this site is required to determine the precise layout of this field and the exact number of pockmarks within it, as well as regular monitoring of this area to determine the level of gas seepage activity which may represent a potential hazard to any planned economic activity in the bay.

A pockmark field in a similar setting has been described in Dunmanus Bay, south of Bantry Bay (Szpak et al., 2015). These authors showed that the pockmarks were associated with $\mathrm{CH}_{4}$ emissions and argued that the source of the gas was an underlying Dunmanus Fault, via a venting mechanism involving seal failure-renewal cycles. The $\mathrm{CH}_{4}$ from Dunmanus contained only trace levels of $\mathrm{C}_{2}-\mathrm{C}_{4}$ hydrocarbons and it was suggested that methanogenesis also contributed to the gas in this location. The Bantry Bay pockmark field overlies the Owenberg River Fault, which runs along the northwest of Whiddy Island. It is possible that venting in Bantry Bay is controlled by a similar bedrock faulting mechanism as proposed in Dunmanus. Both bays lie in the South Munster Basin and are similar in their geology (Vermeulen et al., 2000). However, a higher contribution of low molecular weight hydrocarbons would be expected if this gas was predominantly thermogenic. Therefore, it is most likely that the gas observed at both of these sites is a combination of thermogenic gas release from underlying faults and biogenic gas produced by methanogenic communities feeding on deeply buried organic material.

Both VC24 and VC27 yielded clear SMTZs, where $\mathrm{CH}_{4}$ diffusing upwards from depth first encounters $\mathrm{SO}_{4}{ }^{2-}$ diffusing downwards from the ocean, which reflect the depth of maximal anaerobic oxidation (Antler et al., 2014; Lin et al., 2016; Valentine, 2002). The decreasing trend of $\mathrm{SO}_{4}{ }^{2-}$ in VC25 suggests complete depletion coinciding with a SMTZ at ca. 10 mbsf. The sub-bottom profile suggests that there is no significant gas penetration into this core whereas there is gas penetration observed in the core location of VC24. This is consistent with the significantly lower $\mathrm{CH}_{4}$ concentrations within the VC25 samples. Analysis of sediments from the deeper SMTZ in VC25 would likely yield similar $\mathrm{CH}_{4}$ concentrations to that of VC24 and VC27. Thus the three cores are indicative of variable rates of upward penetration of gas-rich fluids towards the seafloor.

These SMTZs suggest that microbial communities are consuming $\mathrm{CH}_{4}$ rising from depth as well as $\mathrm{SO}_{4}{ }^{2-}$ diffusing downward from the seafloor above. This signature represents the metabolic pathways of microorganisms involved in the AOM, namely ANME and SRB. At present, it appears that the activity of these microbial communities aids in preventing the release of $\mathrm{CH}_{4}$ to the water column and potentially the atmosphere on a regular basis, reducing the potential impact of this powerful greenhouse gas on global climate. However, as previously mentioned, the pockmark features are indicative of possible recurring episodic expulsions of gas from these sediments and as such the overall $\mathrm{CH}_{4}$ flux from this site is poorly constrained. This is a scenario which is observed in shallow marine seepage environments around the world. It is important for these unique environments to be monitored so that their potential contribution to climate change can be better understood.

PLFA biomarker results provide further evidence of this ongoing microbial activity. High levels of MUFAs and low levels of PUFAs are an indication of the dominant contribution of bacterial communities to sediment biomass (Rajendran et al., 1995, 1992; Taylor and Parkes, 1983; Volkman et al., 1980). Bacteria appear to dominate the microbial ecology in all three vibrocores in this study. Abundances of PUFAs are increased in the surface sediments of VC24, however MUFA abundances are still higher. Interestingly, at 0.8 and 3.9 mbsf in VC24, contributions of MUFAs and PUFAs are similar although MUFAs remain dominant. Comparison of MUFAs $\left(<\mathrm{C}_{19}\right)$ with total brFAs provides an insight to the aerobic/anaerobic conditions in the sediment. Values less than 1 indicate an anaerobic environment whereas values greater than 1 are representative of aerobic conditions (Rajendran et al., 1992). Only the shallower sediments of VC24 (1.12 and 1.08 for 0.03 and $0.27 \mathrm{mbsf}$ respectively) are classified as aerobic using this approach, therefore the overall conditions observed here are anaerobic.

Mid-chain brFAs in marine sediments are often produced by SRB and are used as chemotaxonomic markers for these microorganisms (Dowling et al., 1986; Li et al., 2007). $i \mathrm{C}_{15: 0}, a i \mathrm{C}_{15: 0}, i \mathrm{C}_{16: 0}, i \mathrm{C}_{17: 0}$, and aiC $\mathrm{C}_{17: 0}$ are all reported biomarkers for the Desulfovibrio species of SRB (Dowling et al., 1986; Findlay et al., 1990; Li et al., 2007; Rajendran et al., 1995; Taylor and Parkes, 1983). These compounds were present throughout all three vibrocores taken in Bantry Bay, suggesting a significant contribution of SRB to the microbial ecosystem here. SRB tend to display a higher ratio of $i \mathrm{C}_{15: 0}$ to $a i \mathrm{C}_{15: 0}$ in their PLFA profiles (Dowling et al., 1986). Applying this ratio to the Bantry Bay sediments resulted in substantially higher values observed in VC24 than VC25 or VC27, both of which had similar values. This suggests that SRB are substantially higher contributors to the microbial community of VC24. Elvert et al. determined that $\mathrm{C}_{16: 1 \omega 5}, \mathrm{C}_{17: 1 \omega 6}$, and $c y \mathrm{C}_{17: 0 \omega 5,6}$ were specific membrane fatty acids for SRB of the Desulfosarcinia/Desulfococcus group which were involved in AOM (Elvert et al., 2003). $\mathrm{C}_{16: 1 \omega 5}$ was identified in four samples from the Bantry Bay vibrocores; VC24 0.03 mbsf, VC24 0.27 mbsf, VC27 1.93 mbsf, and VC27 2.96 mbsf. Isotope ratio analysis provided a depleted $\delta^{13} \mathrm{C}$ value of $-46.1 \%$ for this compound at $0.27 \mathrm{mbsf}$ in VC24, compared with those obtained from more ubiquitous bacterial PLFAs; $16: 1 \omega 7$ and 16:0 at $-31.0 \%$ and $-27.7 \%$ respectively. While lipid abundances are low, these depleted values still indicate the possible incorporation of $\mathrm{CH}_{4}$ derived $\mathrm{C}$ into the membranes of these SRB providing evidence of their involvement in AOM at this site.

Archaeal biomarkers are present at all depths in all three vibrocores taken in Bantry Bay. Archaea involved in AOM typically belong to three major anaerobic methanotroph (ANME) consortia (Caldwell et al., 2008). It is generally assumed that ANMEs oxidize and assimilate $\mathrm{CH}_{4}$, following which $\mathrm{CH}_{4}$-derived $\mathrm{C}$ is consumed by the $\mathrm{SRB}$ as $\mathrm{CO}_{2}$ or a partially oxidized intermediate completing the syntrophic reaction (Alperin and Hoehler, 2009). It has been suggested that $C_{20}$ isoprenoids derived from archaeal ether lipids may be specific biomarkers for ANME-2 archaea whilst $\mathrm{C}_{40}$ isoprenoids may be specific for the ANME-1 type (Blumenberg et al., 2004; Brocks and Pearson, 2005). The presence of these compounds within the gas-rich sediments in Bantry Bay further suggests the involvement of AOM mediated by ANME and SRB in limiting gas release at this site. More detailed biogeochemical analysis of these sediments could shed more light on the composition of this particular microbial community with isotopic analysis determining their contribution to AOM. Due to the importance of understanding the 
microbial community structure at shallow gas seepage sites like Bantry Bay, a more detailed phylogenetic study of this site is recommended.

\section{Conclusions}

The upward migration of gas-rich fluids through the sediment column appears to be widespread in upper Bantry Bay, as inferred from chimney-like acoustic zones on sub-bottom profiles and confirmed by shallow SMTZs within sediment cores. Shallow SMTZs are observed both within and outwith a newly identified pockmark field, suggesting that diffuse pore fluid upwelling over wide areas is only locally accompanied by focused flow within conduits. Methanogenesis is taking place within organic-rich Quaternary sediments deposited across the upper Bay prior to and since the last deglaciation. The presence of pockmarks off Whiddy Island may be explained by enhanced gas flux from the underlying Owenberg River Fault and methanogenesis of organic-rich lacustrine sediments pre-dating the LGM that are preserved in bedrock basins.

Fluid flow affects not only the physical nature of the sea-floor in the bay but also the microbial ecosystem. The gas is $\mathrm{CH}_{4}$ with a predominantly biogenic signature. As $\mathrm{CH}_{4}$ flows upwards from its origin it provides a substrate for certain microorganisms to thrive in the shallower sediments above. Archaea, possibly ANMEs, are present in these shallower sediments as are SRB. The $\mathrm{CH}_{4}$ is steadily depleted before it reaches the seafloor and $\mathrm{SO}_{4}{ }^{2-}$ concentrations also become depleted in the opposite direction providing a well-defined SMTZ. This is likely due to AOM carried out by these two groups of microorganisms in a syntrophic relationship, however further work is needed to confirm this pathway. This study suggests that AOM in Bantry Bay is important in limiting $\mathrm{CH}_{4}$ emissions from the seafloor preventing the potential climatic implications of a release of this powerful greenhouse gas to the atmosphere. Similar conditions have been observed in a pockmark field in Dunmanus Bay, to the east of Bantry Bay (Szpak et al. (2015)) and on the Malin Shelf off the north coast of Ireland (Szpak et al. (2012). This indicates that marine $\mathrm{CH}_{4}$ production may be common around the island of Ireland.

Global estimates of the contribution of $\mathrm{CH}_{4}$ from marine seepage sites are highly uncertain (Römer et al., 2014). Release of $\mathrm{CH}_{4}$ to the atmosphere has been observed in Arctic regions, areas particularly vulnerable to climate change, and these releases have been attributed to rising temperatures (Shakhova et al., 2010; Westbrook et al., 2009). As $\mathrm{CH}_{4}$ is a potent greenhouse gas, these releases serve only to increase rates of global climate change. AOM and the microbial consortia involved are important factors in the global methane cycle (Gauthier et al., 2015). For these reasons further study of these sites and their microbial ecology should be prioritised.

\section{Acknowledgements}

The authors would like to thank the INFOMAR program, joint programme between the Geological Survey Ireland and the Marine Institute funded by DCCAE. We also thank the captain and crew of the R.V. Celtic Explorer during the GATEWAYS II campaign (CE14003), which was funded by a ship-time award to Stephen McCarron under the Sea Change strategy with the support of the Marine Research SubProgramme of the Irish National Development Plan 2007-2013. We would like to thank Science Foundation of Ireland (SFI) (Investigators Programme, 16/IA/4520 and iCRAG), the Irish Research Council for supporting the work of those researchers based at Dublin City University. The participation of OGS in the GATEWAYS II campaign was supported by Italian PNRA project IPY GLAMAR (grant number 2009/A2.15), and Daniel Praeg also acknowledges funding from the European Union's Horizon 2020 research and innovation program under the Marie Skłodowska-Curie grant agreement No 656821 (project SEAGAS, 2016-2020). Bulk physical analyses of core samples was carried out at the Coastal and Marine Research Centre (CMRC) at
University College Cork. We also thank Dr. Bart van Dongen and the anonymous reviewers whose input significantly improved this manuscript.

\section{Appendix A. Supplementary data}

Supplementary data to this article can be found online at https:// doi.org/10.1016/j.ecss.2019.05.014.

\section{References}

Abegg, F., Anderson, A.L., 1997. The acoustic turbid layer in muddy sediments of Eckernförde Bay, Western Baltic: methane concentration, saturation and bubble characteristics. Mar. Geol. 137, 137-147.

Acosta, J., Munoz, A., Herranz, P., Palomo, C., Ballesteros, M., Vaquero, M., Uchupi, E., 2001. Pockmarks in the Ibiza Channel and western end of the Balearic Promontory (western Mediterranean) revealed by multibeam mapping. Geo Mar. Lett. 21, $123-130$.

Alain, K., Holler, T., Musat, F., Elvert, M., Treude, T., Krüger, M., 2006. Microbiological investigation of methane- and hydrocarbon-discharging mud volcanoes in the Carpathian Mountains, Romania. Environ. Microbiol. 8, 574-590.

Alperin, M.J., Hoehler, T.M., 2009. Anaerobic methane oxidation by archaea/sulfatereducing bacteria aggregates: 2. Isotopic constraints. Am. J. Sci. 309, 958-984.

Antler, G., Turchyn, A.V., Herut, B., Davies, A., Rennie, V.C.F., Sivan, O., 2014. Sulfur and oxygen isotope tracing of sulfate driven anaerobic methane oxidation in estuarine sediments. Estuar. Coast Shelf Sci. 142, 4-11.

Blumenberg, M., Seifert, R., Reitner, J., Pape, T., Michaelis, W., 2004. Membrane lipid patterns typify distinct anaerobic methanotrophic consortia. Proc. Natl. Acad. Sci. Unit. States Am. 101, 11111-11116.

Boetius, A., Ravenschlag, K., Schubert, C.J., Rickert, D., Widdel, F., Gieseke, A., Amann, R., Jørgensen, B.B., Witte, U., Pfannkuche, O., 2000. A marine microbial consortium apparently mediating anaerobic oxidation of methane. Nature 407, 623-626.

Borges, A.V., Champenois, W., Gypens, N., Delille, B., Harlay, J., 2016. Massive marine methane emissions from near-shore shallow coastal areas. Sci. Rep. 6, 27908.

Brocks, J.J., Pearson, A., 2005. Building the biomarker tree of life. Rev. Mineral. Geochem. 59, 233-258.

Caldwell, S.L., Laidler, J.R., Brewer, E.A., Eberly, J.O., Sandborgh, S.C., Colwell, F.S., 2008. Anaerobic oxidation of methane: mechanisms, bioenergetics, and the ecology of associated microorganisms. Environ. Sci. Technol. 42, 6791-6799.

Clark, P.U., Dyke, A.S., Shakun, J.D., Carlson, A.E., Clark, J., Wohlfarth, B., Mitrovica, J.X., Hostetler, S.W., McCabe, A.M., 2009. The last glacial maximum. Science 80-, 325710 LP - 714.

Cole, D., Stewart, S. a., Cartwright, J. a., 2000. Giant irregular pockmark craters in the palaeogene of the outer moray firth basin, UK north sea. Mar. Pet. Geol. 17, 563-577.

Croker, P.F., Kozachenko, M., Wheeler, A.J., 2005. Gas-related Seabed Structures in the Western Irish Sea (IRL-SEA6), SEA6 Technical Report.

Dondurur, D., Çifçi, G., Drahor, M.G., Coşkun, S., 2011. Acoustic evidence of shallow gas accumulations and active pockmarks in the İzmir Gulf, Aegean sea. Mar. Pet. Geol. 28, 1505-1516.

Dowling, N.J.E., Widdel, F., White, D.C., 1986. Phospholipid ester-linked fatty acid biomarkers of acetate-oxidizing sulphate-reducers and other sulphide-forming bacteria. Microbiology 132, 1815-1825.

Elvert, M., Boetius, A., Knittel, K., Jørgensen, B.B., 2003. Characterization of specific membrane fatty acids as chemotaxonomic markers for sulfate-reducing bacteria involved in anaerobic oxidation of methane. Geomicrobiol. J. 20, 403-419.

Etiope, G., Milkov, A., Derbyshire, E., 2008. Did geologic emissions of methane play any role in Quaternary climate change? Glob. Planet. Chang. 61, 79-88.

Faber, E., Stahl, W., 1984. Geochemical surface exploration for hydrocarbons in North Sea. Am. Assoc. Petrol. Geol. Bull. 68, 363-386.

Field, M.E., Jennings, A.E., 1987. Seafloor gas seeps triggered by a northern California earthquake. Mar. Geol. 77, 39-51.

Findlay, R.H., Trexler, M.B., Guckert, J.B., White, D.C., 1990. Laboratory study of disturbance in marine sediments: response of a microbial community. Mar. Ecol. Prog. Ser. Oldend, 62, 121-133.

Fleischer, P., Orsi, T., Richardson, M., Anderson, A., 2001. Distribution of free gas in marine sediments: a global overview. Geo-Marine Lett. 21, 103-122.

Floodgate, G.D., Judd, a. G., 1992. The origins of shallow gas. Cont. Shelf Res. 12, 1145-1156.

Froelich, P.N., Klinkhammer, G.P., Bender, M.L., Luedtke, N.A., Heath, G.R., Cullen, D., Dauphin, P., Hammond, D., Hartman, B., Maynard, V., 1979. Early oxidation of organic matter in pelagic sediments of the eastern equatorial Atlantic: suboxic diagenesis. Geochem. Cosmochim. Acta 43, 1075-1090.

Gauthier, M., Bradley, R.L., Šimek, M., 2015. More evidence that anaerobic oxidation of methane is prevalent in soils: is it time to upgrade our biogeochemical models? Soil Biol. Biochem. 80, 167-174.

Gay, a., Lopez, M., Berndt, C., Séranne, M., 2007. Geological controls on focused fluid flow associated with seafloor seeps in the Lower Congo Basin. Mar. Geol. 244, 68-92.

Ge, L., Jiang, S.-Y., Blumenberg, M., Reitner, J., 2015. Lipid biomarkers and their specific carbon isotopic compositions of cold seep carbonates from the South China Sea. Mar. Pet. Geol. 66, 501-510.

Hammer, Ø., Webb, K.E., Depreiter, D., 2009. Numerical simulation of upwelling currents in pockmarks, and data from the Inner Oslofjord, Norway. Geo Mar. Lett. 29, 
269-275.

Hasiotis, T., Papatheodorou, G., Kastanos, N., Ferentinos, G., 1996. A pockmark field in the Patras Gulf (Greece) and its activation during the 14/7/93 seismic event. Mar. Geol. 130, 333-344.

Hovland, M., 1989. The formation of pockmarks and their potential influence on offshore construction. Q. J. Eng. Geol. Hydrogeol. 22, 131-138.

Hovland, M., 2013. Characteristics of marine methane macroseeps. In: Aminzadeh, F., Berge, T.B., Connolly, D.L. (Eds.), Hydrocarbon Seepage: from Source to Surface. Society of Exploration Geophysicists (SEG), and American Association of Petroleum Geologists (AAPG), pp. 63-82.

Hovland, M., Gardner, J.V., Judd, a. G., 2002. The significance of pockmarks to understanding fluid flow processes and geohazards. Geofluids 2, 127-136.

Hovland, M., Judd, A.G., 1988. Seabed Pockmarks and Seepages: Impact on Geology, Biology, and the Marine Environment. Graham and Trotman, London.

INFOMAR, 2011. Bantry \& Dunmanus Bay Acoustic Seabed Classification Chart. Geological Survey of Ireland and Marine Institute, Ireland.

Janssen, F., Huettel, M., Witte, U., 2005. Pore-water advection and solute fluxes in permeable marine sediments (II): benthic respiration at three sandy sites with different permeabilities (German Bight, North Sea). Limnol. Oceanogr. 50, 779-792.

Joye, S.B., Connell, T.L., Miller, L.G., Oremland, R.S., Jellison, R.S., 1999. Oxidation of ammonia and methane in an alkaline, saline lake. Limnol. Oceanogr. 44, 178-188.

Judd, A., Hovland, M., 2007. Seabed Fluid Flow - the Impact on Geology, Biology and the Marine Environment. Cambridge University Press, Cambridge.

King, L.H., MacLean, B., 1970. Pockmarks on the scotian Shelf. Geol. Soc. Am. Bull. 81, 3141-3148.

King, L.L., Pease, T.K., Wakeham, S.G., 1998. Archaea in Black Sea water column particulate matter and sediments-evidence from ether lipid derivatives. Org. Geochem. $28,677-688$.

Knittel, K., Boetius, A., 2009. Anaerobic oxidation of methane: progress with an unknown process. Annu. Rev. Microbiol. 63, 311-334.

Li, Y., Peacock, a, White, D., Geyer, R., Zhang, C., 2007. Spatial patterns of bacterial signature biomarkers in marine sediments of the Gulf of Mexico. Chem. Geol. 238, 168-179.

Lin, Q., Wang, J., Algeo, T.J., Sun, F., Lin, R., 2016. Enhanced framboidal pyrite formation related to anaerobic oxidation of methane in the sulfate-methane transition zone of the northern South China Sea. Mar. Geol. 379, 100-108.

Locat, J., Lee, H.J., 2002. Submarine landslides: advances and challenges. Can. Geotech. J. 39, 193-212.

Mathys, M., Thießen, O., Theilen, F., Schmidt, M., 2005. Seismic characterisation of gasrich near surface sediments in the Arkona Basin, Baltic Sea. Mar. Geophys. Res. 26, 207-224.

Navarrete, A., Peacock, A., Macnaughton, S., Urmeneta, J., Mas-Castellà, J., White, D., Guerrero, R., 2000. Physiological status and community composition of microbial mats of the ebro delta, Spain, by signature lipid biomarkers. Microb. Ecol. 39, 92-99.

Nichols, P.D., Guckert, J.B., White, D.C., 1986. Determination of monosaturated fatty acid double-bond position and geometry for microbial monocultures and complex consortia by capillary GC-MS of their dimethyl disulphide adducts. J. Microbiol. Methods $5,49-55$.

Niemann, H., Elvert, M., 2008. Diagnostic lipid biomarker and stable carbon isotope signatures of microbial communities mediating the anaerobic oxidation of methane with sulphate. Org. Geochem. 39, 1668-1677.

O'Reilly, S.S., Hryniewicz, K., Little, C.T.S., Monteys, X., Szpak, M.T., Murphy, B.T., Jordan, S.F., Allen, C.C.R., Kelleher, B.P., 2014. Shallow water methane-derived authigenic carbonate mounds at the Codling Fault Zone, western Irish Sea. Mar. Geol. 357, 139-150.

Pancost, R.D., Sinninghe Damste, J.S., de Lint, S., van der Maarel, M.J.E.C., Gottschal, J.C., 2000. Biomarker evidence for widespread anaerobic methane oxidation in mediterranean sediments by a consortium of methanogenic archaea and bacteria. Appl. Environ. Microbiol. 66, 1126-1132.

Pau, M., Gisler, G., Hammer, $\varnothing$., 2014. Experimental investigation of the hydrodynamics in pockmarks using particle tracking velocimetry. Geo Mar. Lett. 34, 11-19.

Pinkart, H.C., Devereux, R., Chapman, P.J., 1998. Rapid separation of microbial lipids using solid phase extraction columns. J. Microbiol. Methods 34, 9-15.

Plets, R.M.K., Callard, S.L., Cooper, J.A.G., Long, A.J., Quinn, R.J., Belknap, D.F., Edwards, R.J., Jackson, D.W.T., Kelley, J.T., Long, D., Milne, G.A., Monteys, X., 2015. Late Quaternary evolution and sea-level history of a glaciated marine embayment, Bantry Bay, SW Ireland. Mar. Geol. 369, 251-272.

Rajendran, N., Matsuda, O., Imamura, N., Urushigawa, Y., 1992. Variation in microbial biomass and community structure in sediments of eutrophic bays as determined by phospholipid ester-linked fatty acids. Appl. Environ. Microbiol. 58, 562-571.

Rajendran, N., Matsuda, O., Imamura, N., Urushigawa, Y., 1995. Microbial community structure analysis of euxinic sediments using phospholipid fatty acid biomarkers. J. Oceanogr. 51, 21-38.

Reeburgh, W.S., 2007. Oceanic methane biogeochemistry. Chem. Rev. 107, 486-513.
Ringelberg, D.B., Sutton, S., White, D.C., 1997. Biomass, bioactivity and biodiversity: microbial ecology of the deep subsurface: analysis of ester-linked phospholipid fatty acids. FEMS Microbiol. Rev. 20, 371-377.

Römer, M., Torres, M., Kasten, S., Kuhn, G., Graham, A.G.C., Mau, S., Little, C.T.S., Linse, K., Pape, T., Geprägs, P., Fischer, D., Wintersteller, P., Marcon, Y., Rethemeyer, J., Bohrmann, G., 2014. First evidence of widespread active methane seepage in the Southern Ocean, off the sub-Antarctic island of South Georgia. Earth Planet. Sci. Lett. 403, 166-177.

Ruff, S.E., Kuhfuss, H., Wegener, G., Lott, C., Ramette, A., Wiedling, J., Knittel, K., Weber, M., 2016. Methane seep in shallow-water permeable sediment harbors high diversity of anaerobic methanotrophic communities, elba, Italy. Front. Microbiol. 7, 374.

Schouten, S., Hopmans, E.C., Sinninghe Damsté, J.S., 2013. The organic geochemistry of glycerol dialkyl glycerol tetraether lipids: a review. Org. Geochem. 54, 19-61.

Shakhova, N., Semiletov, I., Salyuk, A., Yusupov, V., Kosmach, D., Gustafsson, O., 2010. Extensive methane venting to the atmosphere from sediments of the east siberian arctic Shelf. Science 327, 1246-1250.

Skarke, A., Ruppel, C., Kodis, M., Brothers, D., Lobecker, E., 2014. Widespread methane leakage from the sea floor on the northern US Atlantic margin. Nat. Geosci. 7, $657-661$.

Soter, S., 1999. Macroscopic seismic anomalies and submarine pockmarks in the Corinth-Patras rift, Greece. Tectonophysics 308, 275-290.

Stillman, C.J., 1968. The Post Glacial Change in Sea Level in Southwestern Ireland: New Evidence from Fresh-Water Deposits on the Floor of Bantry Bay. The scientific proceedings of the Royal Dublin Society. Royal Dublin Society.

Szpak, M.T., Monteys, X., O'Reilly, S., Simpson, A.J., Garcia, X., Evans, R.L., Allen, C.C.R., McNally, D.J., Courtier-Murias, D., Kelleher, B.P., 2012. Geophysical and geochemical survey of a large marine pockmark on the Malin Shelf, Ireland. Geochem. Geophys. Geosyst. 13.

Szpak, M.T., Monteys, X., O'Reilly, S.S., Lilley, M.K.S., Scott, G.A., Hart, K.M., McCarron, S.G., Kelleher, B.P., 2015. Occurrence, characteristics and formation mechanisms of methane generated micro-pockmarks in Dunmanus Bay, Ireland. Cont. Shelf Res. 103, 45-59.

Taylor, J., Parkes, R.J., 1983. The cellular fatty acids of the sulphate-reducing bacteria, desulfobacter sp., desulfobulbus sp. and Desulfovibrio desulfuricans. Microbiology 129, 3303-3309.

Trent, J.D., Kagawa, H.K., Paavola, C.D., McMillan, R.A., Howard, J., Jahnke, L., Lavin, C., Embaye, T., Henze, C.E., 2003. Intracellular localization of a group II chaperonin indicates a membrane-related function. Proc. Natl. Acad. Sci. U.S.A. 100, 15589-15594.

Valentine, D.L., 2002. Biogeochemistry and microbial ecology of methane oxidation in anoxic environments: a review. Antonie Leeuwenhoek 81, 271-282.

Valentine, D.L., Reeburgh, W.S., 2000. New perspectives on anaerobic methane oxidation. Environ. Microbiol. 2, 477-484.

van Dongen, B.E., Roberts, A.P., Schouten, S., Jiang, W.-T., Florindo, F., Pancost, R.D. 2007. Formation of iron sulfide nodules during anaerobic oxidation of methane. Geochem. Cosmochim. Acta 71, 5155-5167.

Verardo, D.J., Froelich, P.N., McIntyre, A., 1990. Determination of organic carbon and nitrogen in marine sediments using the Carlo Erba NA-1500 analyzer. Deep Sea Res. Part A. Oceanogr. Res. Pap. 37, 157-165.

Vermeulen, N.J., Shannon, P.M., Masson, F., Landes, M., 2000. Wide-angle seismic control on the development of the Munster Basin, SW Ireland. Geol. Soc. London, Spec. Publ. 180, 223-237.

Volkman, J.K., Johns, R.B., Gillan, F.T., Perry, G.J., Bavor, H.J., 1980. Microbial lipids of an intertidal sediment-I. Fatty acids and hydrocarbons. Geochem. Cosmochim. Acta 44, 1133-1143.

Wakeham, S.G., Lewis, C.M., Hopmans, E.C., Schouten, S., Sinninghe Damsté, J.S., 2003. Archaea mediate anaerobic oxidation of methane in deep euxinic waters of the Black Sea. Geochem. Cosmochim. Acta 67, 1359-1374.

Westbrook, G.K., Thatcher, K.E., Rohling, E.J., Piotrowski, A.M., Pälike, H., Osborne, A.H., Nisbet, E.G., Minshull, T.A., Lanoisellé, M., James, R.H., Hühnerbach, V., Green, D., Fisher, R.E., Crocker, A.J., Chabert, A., Bolton, C., Beszczynska-Möller, A., Berndt, C., Aquilina, A., 2009. Escape of methane gas from the seabed along the West Spitsbergen continental margin. Geophys. Res. Lett. 36.

Wheeler, A.J., 2002. Environmental controls on shipwreck preservation: the Irish context. J. Archaeol. Sci. 29, 1149-1159.

White, D.C., Ringelberg, D.B., MacNaughton, S.J., Srinivas, A., Schram, D., 1997. Signature lipid biomarker analysis for quantitative assessment in situ of environmental microbial ecology. In: Eganhouse, R.P. (Ed.), Molecular Markers in Environmental Chemistry. American Chemical Society, Washington D.C., pp. 22-34.

Yvon-Durocher, G., Allen, A.P., Bastviken, D., Conrad, R., Gudasz, C., St-Pierre, A., Thanh-Duc, N., del Giorgio, P.A., 2014. Methane fluxes show consistent temperature dependence across microbial to ecosystem scales. Nature 507, 488-491.

Zelles, L., 1997. Phospholipid fatty acid profiles in selected members of soil microbial communities. Chemosphere 35, 275-294. 